\title{
Economic Determinants of the Natural Fertility Rate with Special Focus on the EU and on Hungary
}

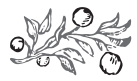

\section{Summary}

The natural fertility rate directly expresses the reproductive capabilities of a country. Typically, the value of this indicator is considerably lower in the economically developed part of the world than in less developed countries. However, in terms of fertility rates, developed countries are not completely homogenous either, at least in an analysis of changes in time series. Through the example of various EU Member States, this study aims to pick the economic and policy factors that may trigger improvement in the fertility rate. Apart from a few countries, it is a common problem in the surveyed states that population growth is insufficient for ensuring reproduction. Paradoxically, population decline and ageing is a problem in those countries and regions of the world where the material, economic and welfare conditions are the most favourable. It is also important to demonstrate globally detectable correlations between fertility rates and the standard of living. The aim of this study is to highlight the specific social and economic indicators with the most beneficial and most adverse impacts on developments in fertility rates. An important finding of the study is that having children is essentially not an economic, much rather a cultural matter that is closely related to the concept of responsibility, and in addition, economic stability or a balanced income distribution may increase the fertility rate. Overall, decrease in the intensity of childbearing can be considered as a legitimate concomitant of societies with advanced economies. In the study references are made to other variables that

Dr Tibor Pintér, Associate Professor, Budapest Business School, Faculty of Commerce, Catering and Tourism, Department of Economics (Pinter.Tibor@uni-bge.hu). 
may shift the unfavourable demographic trends in a more favourable direction in the developed world.

Journal of Economic Literature (JEL) codes: J10, J13, F63, I15

Keywords: fertility rate, economic development, social assistance, ageing, income growth

\section{INTRODUCTION}

This study aims to identify the economic determinants of fertility rate. It is common knowledge that the insufficient number of children usually poses a serious problem exactly in countries with ample economic resources. Childbearing and family support are also emphatic in today's Hungarian public debates. On the one hand, this can be seen as a very welcome development and a sign that the political leadership has realised the increasing challenge this issue poses in the developed world. However, more emphasis should be placed on the cultural, personal and emotional aspects of this problem, and the latter are just as important in a decision to start a family as financial considerations are. Surveys, databases and everyday experience suggest that a clearly positive emotional and ideological motivation underlies every decision to start a family.

Allow me to only point out two correlations to prove that finances will not solve the fertility crisis on a global scale. Based on the relevant 2016 data published by the World Bank, nearly 85 per cent of the world's population live below the average Hungarian's standard of living. In spite of this, in Hungary the fertility rate is considerably below the world average and the natural reproductive value.

Similar data is related to time trends. In 1960, the fertility rate of an average earthling was nearly 5, with approximately 450 USD per capita GDP. In 2016 (56 years later), a fertility rate of 2.44 is coupled with USD 10,200 per capita GDP. This is not to say that a fertility rate of 5 is desirable, but the trend is more than though-provoking.

However, this study does not have such a distressing message. The group of economically highly developed countries, namely the 28 Member States of the European Union, give a more intricate picture.

\section{THEORETICAL OVERVIEW AND RESEARGH QUESTIONS}

In its early stages, economics addressed the matters and areas affected by economic developments more naturally. The implementation of an economic system capable of creating the material needs of a decent family life can be considered such an area. Although the current economic system has created extraordinary riches, it does not at all support family life. In this respect this economic system has failed. Naturally, this failure is not a bolt from the blue. 
Following the early economic theories covering a broad horizon, the classical school of economics (hallmarked by Adam Smith) systematically organised the conceptual and methodological toolbox of this academic field (Mueller, 2010). However, this development isolated the representatives of this discipline and encouraged them to specialise. Since then, only theoretical economists working in various specific fields have been dealing with, say, the demographic aspects and demographic sustainability of the economic system. Within this scope, mention must be made of the work of Thomas Robert Malthus, who suggested in his book, originally published in 1798, that the population growth rate and the potential of economic performance should be compared. His conclusion that global population growth would be permanently higher than economic growth was, of course, incorrect. Regardless of this fact, it should be pointed out that massive population growth is not characteristic in areas where one would expect it on the basis of economic performance and the standard of living. The longer the time series, the stronger discrepancies can be found in this research area.

The correlation between a variable considered important in any academic discipline and the population and demographic developments gives rise to the question whether the fertility rate is a suitable indicator as a dependent variable. A review of the relevant literature has shown that in most cases this indicator can indeed be used as a dependent variable in various models (Becker, 1960; Berde and Németh, 2016).

Another important question is whether there is any relation between the level of economic development and the fertility rate. Although GDP and SNA indicators are frequently criticised in economic analyses, in most cases, demographic trends are compared to GDP or an indicator derived from it (Berde and Kuncz, 2017). In an economic historical perspective, there is a definitely adverse correlation between income levels and fertility; and specific fertility-related theories have emerged to explain this phenomenon, but they have been unable to give a satisfactory answer (Jones and Schoonbroodt, 2010).

Another important trend in the economic analysis of fertility, inspired by economic history, includes the efforts made at identifying the level of economic development where the dynamics of fertility breaks and the way demographic development is related to the series of economic transitions. The need to map correlation between economic transition and the fertility rate arises in highly developed regions (Prskawetz and Lindh, 2007), in isolated areas with medium income levels (Mason et al., 2010), and in bigger countries with low development levels (Hussain et al., 2009). The recent serious global economic crisis has also had a controversial impact on the world's most developed regions (Sobotka et al., 2011).

The assessment of a correlation between the demographic developments, economic performance and the standard of living (Berde and Kovács, 2016) is genuinely important in the case of countries that are considered well-developed in a global comparison and have extensive welfare systems and functioning social security systems (Sági et al., 2018), because (as shown in the charts below) the willingness to have children is typically much lower in these regions of the world. In addition, the correlation between the two phenomena is not explicitly highly adverse in this income 
range, but there is a weak positive correlation. In any case, it can be concluded that a sort of alternative value system is built up in the more developed societies in relation to childbirth (Schultz, 1974).

The directions of intervention and the opportunities of fiscal policy and active state involvement also emerge as major research questions in this context (Yang, 2016). Even though there are differences between the various pension systems, it is important to note that the lower number of children and the accompanying phenomenon of ageing are alarming trends that will need to be addressed in the future (Széll, 2010). Both the academic and the political stakeholders need to deal with the available implementation opportunities.

A direct financial correlation can be established between having children, starting a family and the social security system (Giday and Szegó, 2018). Economic growth has a clearly favourable impact on the life expectancy of a country's population but this does not mean that improvement in health is necessary for starting a family (Barro, 2013). Thus, at a later stage, it may be worthwhile to explore the interrelationship between health and economic performance, as well as the correlation between certain civilization diseases and economic performance. It is worth noting that during my other surveys I found a very strong positive correlation between the ratio of population with cancer and economic development, however, the exploration of this correlation falls outside the scope of the present study.

As a special question (for example, in the context of sociological and regional studies), the exploration of the territorial context of fertility may also be important (Varga, 2005). In a country or other territorial unit, it is exactly the younger population willing to start a family who often move to more prosperous areas (Sági and Lentner, 2018). Many of them do not ultimately have the previously planned number of children, precisely because of the newly adopted attitudes. There is a rationale behind research in countries with similar development historical heritage and similar roles in the international division of labour. For this very reason, Farkas (2017) compares the functioning of the family support systems in Poland, the Czech Republic and Slovakia and draws conclusions with respect to the Hungarian system.

It is also worth highlighting the controversial relationship between the labour market participation and qualification of women and fertility rates (Yang, 2000). Accordingly, there is a clearly adverse correlation between women's active participation in the labour market and fertility, however, this correlation is not so clear in the developed parts of the world. In the range below the natural reproductive level, there is a positive correlation between active female participation in the labour market and the willingness to have children. The special theoretical economic categories and variables such as unemployment and its social consequences, including the psychological basis of the attitude towards having children, can also show a correlation with each other (Kucséber, 2011). Thus, a person living in a more developed country may feel that losing a job is a sufficient reason to postpone having children. However, based on the databases, this is more of a sociological and psychological consideration, since globally a higher standard of living clearly reverses the fertility rate. 
In this study efforts are made at demonstrating correlations solely between data and nothing else. Naturally, this presupposes the knowledge of the most important types of empirical methods. The relevant Hungarian literature has also undergone significant development in recent years. The basic tables were compiled and the analyses were conducted primarily on the basis of the work of Molnár (2015). However, a book published by Dusek and Kotosz in 2016 has provided an excellent complementation, especially by a more sophisticated, elaborate interpretation and data collection.

It is worth reviewing the magnitude of differences in economic development and in fertility rates between the large regions of the world. Instead of merely drawing a static cross-section of the present, it is worth including the temporal changes in fertility and economic development over time. Following this, however, focus falls on the EU Member States, where the reliability of statistical systems may be higher and which are in a similar social and economic situation to Hungary. The most important economic determinants of fertility are identified through direct economic, sociological and regional economic variables. Mostly, the regression model analysis and correlation matrixes are used to highlight the main directions and relationships.

\section{CORRELATION BETWEEN THE FINANGIAL STANDARD OF LIVING AND FERTILITY RATES IN A GLOBAL PERSPECTIVE}

It is important to demonstrate the correlation between the economic standard of living and fertility rate. Despite its known weaknesses, per capita GDP is used to measure the economic standard of living. The first chart gives a summary of GDP per capita and fertility rates in all the countries of the world in a scatter diagram. The number of sample elements is less than the number of countries, because only countries where both data are available for 2016 have been added to the model.

The following chart shows a negative correlation between GDP per capita and the fertility rate. This correlation is not linear, but rather gives an exponential shape.

The Chart 1 gives a static, cross-sectional correlation between the two data in the same calendar year 2016. The correlation coefficient in the chart shows the accuracy of matching the cloud of points containing real data to the hypothetical logarithmic model. According to the additional model calculations performed by the SPSS program, the results of both the logarithmic regression model and the correlation model are significant. The value of the Pearson correlation indicator is -0.488 , which gives a negative, but not particularly high correlation between GDP per capita and the fertility rate. It is important to note that in terms of GDP per capita (shown on the horizontal axis to show the extent to which the standard of living defines fertility and the dependence of the latter on the former), the points are characterized by different locations. It is clearly visible that in the case of poorer countries, a higher fertility rate of 3 or more is fairly common, while in richer countries a value higher than 2 or 2.5 is rarely found for the same, and values below 2 are more typical.

In 2016, Niger's fertility rate was the highest at 7.24 (rounded to two decimal places), followed by two other African countries: Somalia and the Democratic Republic of 
Chart 1: Correlation between fertility rates and GDP per capita in the world's countries, 2016

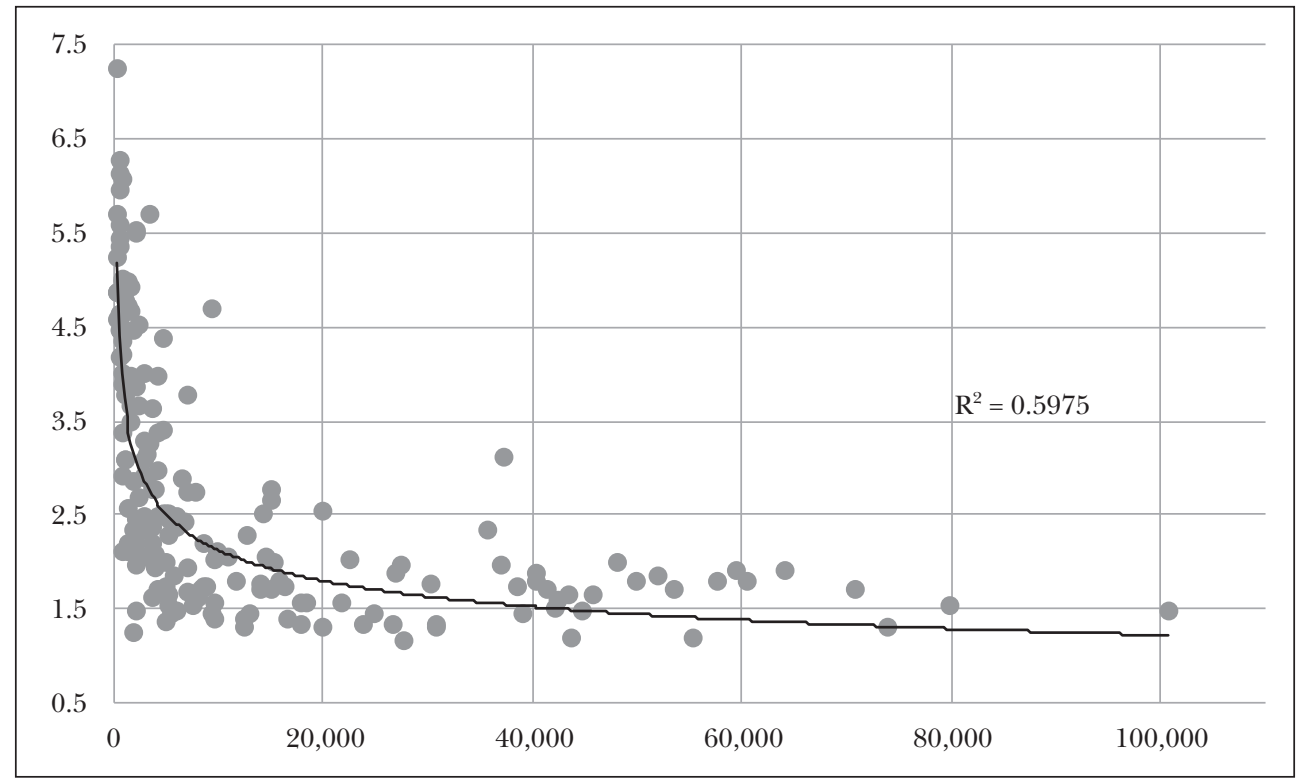

Source: Based on data from the World Bank

Congo, both with values well over 6 . South Korea had the lowest measured value in the world in 2016: 1.117, followed by Singapore and Hong Kong, both with very low indicators around 1.2. Within the group having GDP over 20000 USD per person, only Guam and Israel have a fertility rate above 2 , the latter with a value above 3 . This supplement illustrates a higher negative correlation than the indicators, and moreover, the overall population is more concentrated in countries falling in lower income categories, i.e. countries with large populations fall into this income group.

In addition to the analysis of the situation in a given time, a time series analysis is also important. This second model analyses the correlation between the fertility rate and GDP per capita of an average citizen of the world. Chart 2 shows the evolution of these two indicators per annum in the period between 1960 and 2016. The negative correlation between the movements of the two variables is clearly higher.

This chart shows a negative exponential correlation, with the real data almost matching the hypothetical function $\left(\mathrm{R}^{2}=0.9727\right.$, a very strong link in a quasi social and economic analysis). The correlation is also high: the rate (Pearson's coefficient) is -0.897 . According to SPSS, the correlation is also significant if the value is 1 per cent. Thus it can be stated without any hesitation that the rapid rise in the standard of living seen in the past few decades has adversely affected development in fertility rates. Although the trend of overpopulation continues, the global fertility rate is getting closer to the value of 2 . However, the chart suggests that decrease in fertility is slowing, and decline is far from the massive drop seen in the middle of the period. Another important conclusion is that although the term "population explosion" is not directly 
Chart 2: Correlation between fertility rates and GDP per capita, based on average values per person, 1960-2016

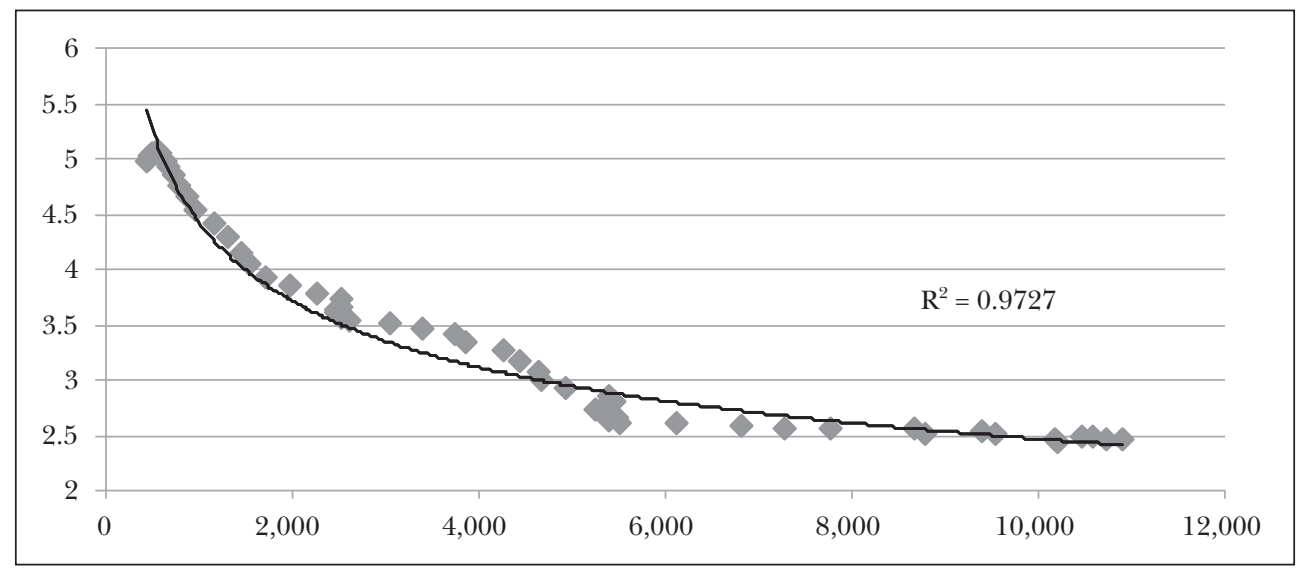

Source: Based on data from the World Bank

used to refer to the past few decades, at least in the Western world, it should rather be replaced by "economic explosion" to describe this period, since the average standard of living has increased twenty-fold in 56 years, adjusted for population growth.

\section{Correlation betweEn THE FERTILity RATE AND its ECONOMiC} Determinants in the 28 Member States of the European Union

In terms of global development, it can be concluded that overall, there is a negative correlation between the standard of living and the fertility rate. A stronger negative effect is reflected in the time series, i.e. decline in the fertility rate is clearly associated with improvement in the economic development. However, in addition to a dynamic approach, the static model, which includes the analysis of a single year, showed a lower correlation in a similar direction. In both cases, the correlations were considered significant. In light of this, the result of the model where the scope of observation units was limited to the current 28 Member States of the European Union can be considered rather surprising.

This chapter describes the result of an analysis of the correlation between 19 economic variables and the fertility rate. An effort was made at selecting the variables that have a high level of measurement and include welfare, stability, sociological and territorial (regional economic) criteria. The following variables were included: GDP per capita, ratio of urban population, employment rate, GINI coefficient, ratio of R\&D expenditures to GDP in exports, number of hours worked per week, ratio of population living in metropolitan areas, unemployment rate, ratio of internet users within the population, CPI (corruption perception index), Bertelsmann Sustainable Governance Indicators, Happy Planet Index, ratio of domestic loan to GDP, final consumption expenditure to GDP, household consumption to GDP, military expenditure to GDP, ratio of non-performing bank loans, ratio of net public social transfers to GDP. 
Of all the variables, the following table only includes the significant correlation coefficients. Nevertheless, in the explanation, the direction of non-significant variables is also included.

Table 1: Correlation coefficients in the fertility rate and the significant economic variables (mostly 2016)

\begin{tabular}{l|c}
\hline Included economic variable & Correlation with the fertility rate \\
\hline GDP per capita & $0.395^{*}$ \\
\hline Employment rate & $0.544^{* *}$ \\
\hline R\&D exp 2014 & $0.455^{*}$ \\
\hline Hours worked & $-0.442^{*}$ \\
\hline Unemployment & $-0.394^{*}$ \\
\hline Internet users & $0.479 * *$ \\
\hline CPI & $0.548^{* *}$ \\
\hline Bertelsmann Sust & $0.398^{*}$ \\
\hline Bank nonperforming loan & $-0.438^{*}$ \\
\hline
\end{tabular}

Source: Author's calculation based on data from the World Bank and Eurostat

Based on the above table and on other information, certain conclusions can be drawn about the fertility rate and its economic determinants. The table shows the Pearson correlation coefficients, which indicate the closeness and direction of the correlation per pair. One asterisk indicates that the value of the two-tailed significance is valid within the 5-percent interval, while two asterisks denote validity within 1 per cent, in other words, validity is even higher in the latter range. As none of the values is exceptionally high, it cannot be condfirmed that they are strong economic determinants of the fertility rate.

In an absolute value, the CPI (the corruption perception index) and the employment rate have the highest numerical values. Both show positive correlations. In light of the method of creating these indicators, the conclusion arises that the less corrupt a society is (the value of the indicator increases if corruption is not perceived or less perceived), the more positive shift can be expected in fertility. In addition to the absence of corruption (which may naturally be measured with an excessively normative content), the employment rate of a country has also proved to be decisive (maitaining that neither of the coefficients is particularly high). This can be construed in a way that active participation in the labour market functions as a kind of an existential basis to underpin the willingness to have children. A higher ratio of internet users and a more pronounced presence of R\&D-intensive products within exports show a lower but positive correlation. This suggests that the level of scientific/academic development and qualification can indirectly improve fertility rates in the case of a country with a high 
standard of living. Globally, the exact opposite can be seen for these variables; however, limiting our analysis to developed countries reverses the direction of the correlation.

GDP per capita and the Sustainable Governance Indicator of the Bertelsmann Institute show positive correlations of similar strength. Especially the former one is a surprise, given that globally, both in a given year and in the time series, GDP per capita has a clearly negative correlation with fertility. In the 28 Member States of the $\mathrm{EU}$, however, there is a slightly positive correlation between fertility and the standard of living. Consequently, in the case of an EU Member State, fincncial incentives to support having children cannot be considered needless, at least if the fertility rate falls between 1 and 2. This result contradicts the preliminary research expectation that the EU would also have the usual adverse trend.

Only three of all the significant variables show a negative correlation with the fertility rate. These are the number of hours worked, the ratio of non-performing bank loans to the total loans, and the unemployment rate. The more time people spend at work; the lower fertility rate is reported. This seems to be self-evident, however, as the correlation with employment is positive, it is important to draw the attention to the fact that the barrier to childbearing is not employment in itself, but poorly organised, unmanageable work and long working hours. Consequently, flexible working hours and efficient work should be set as immanent objectives in legislation and management. This could further resolve the conflict between work and family.

Despite the fact that, representing a non-characteristic correlation, the indicator of non-performing loans remains below 0.5 in an absolute value, it is still necessary to explain this variable. It suggests that the willingness to have children is reduced by insufficiently covered private-sector loans. This correlation shows similarities to what has already been explained above, namely that existential security is at risk not olny if a person does not have secure employment but also when revenues are insufficient to finance debt payment. Therefore, it is worth considering that support to fertility should be conceptually linked with improving the financial literacy and providing a stable financial system in a country. This is only confirmed by previous analyses not covered in this study, like those related to risk factors (e.g. the EOS risk factor of the World Economic Forum) in certain countries, which have shown that relieving a country from risk factors has a beneficial impact on the fertility path.

Non-significant correlations exhibited the following trends: The ratio of urban population and the ratio of population in metropolitan areas have a very slight positive correlation with fertility. The GINI coefficient shows a low negative correlation with fertility, i.e. unequal income distribution is more likely to discourage having children. The Happy Planet Index has a neutral value (0.052), while the ratio of loans, household and end-user consumption, and military expenditures, and the ratio of net public social transfers to GDP all adversely affect fertility. Thus, the expansion of the social welfare system alone is not a particularly important factor, while consumption has more of an adverse effect. A comparison of the ratio of family support expenditure to GDP (only OECD data are available for OECD countries, so the basic model changes) reveals a very low positive correlation coefficient at 0.06 . 
Tibor Pintér: Economic Determinants of the Natural Fertility Rate with Special Focus...

\section{DEVELOPMENTS IN THE FERTILITY RATE IN HUNGARY \\ AND ITS ECONOMIC BACKGROUND}

In Hungary the incumbent government places great emphasis on demography. The most recent cornerstone in the relevant policy actions is the 7-point family protection action plan announced in February 2019. The presented fertility rates also justify that the Member States of the European Union, including Hungary, are generally characterised by extremely low fertility rates, and this alone jeopardises the sustainability of the social and economic system. Various concepts, either using external resources or merely by improving the productivity of the internal population, have been set up for solving this crisis and in public discourse the key role of economic policy acions in the provision of a solution is called into question. Although these are not insignificant questions, as they are not strictly economic, they fall outside the scope of this study.

In an analysis of developments in the Hungarian fertility rate, it needs to be noted as a preliminary point that Hungary has also been unable to detach itself from the European trend of declining fertility rates with improvement in the standard of living. This statement is not as simple as it may seem at first sight, because it is only true if the standard of living is expressed in the internationally accepted SNA indicators. In this study GDP per capita is used at purchasing power parity to express welfare. Naturally, certain questions are not addressed at the moment, including: What is the relationship between the two categories if real wages are taken into consideration? What is the relationship if growth financed from indebtedness or foreign capital is distinguished from growth based on internal resources? The experiences of the past few years suggest that people tend to make decisions, among others on having children, more on the basis of such economic parameters perceivable in daily life..

The following chart shows the evolution of the fertility rate of Hungary after 1942. The indicator had clearly decreased from a rate above 2 to a rate below 2 already by 1970 , with the lowest rate at 1.23 in 2011 , followed by gradual increase in the fertility rate to 1.49 in 2017.

Chart 3 depicts a social and economic historical transition in Hungary from traditional values to a preference for a high standard of living considered worth giving up even demographical sustainability. The above firm political will and the aforementioned claim that a slightly positive correlation is demonstrable between GDP per capita and fertility in countries with a higher standard of living somewhat sophisticates the Hungarian situation.

Béla Tomka writes in his book published in 2016 that in the cross-hairs of Hungarian society and politics Austria has played an important role as a benchmark. Below the Hungarian state of affairs is compared to the Austrian standard of living rather than to the average of the EU (although the latter would show a similar trend). The following chart presents developments in GDP per capita at purchasing power parity and in the fertility rate in Hungary after the change of regime, relative to Austria. Theoretically, this was an important benchmark for the Hungarian society and also the Hungarian political elite. Chart 4 has too vertical axes: the left one measures de- 
Chart 3: Fertility rates in Hungary, 1941-2017

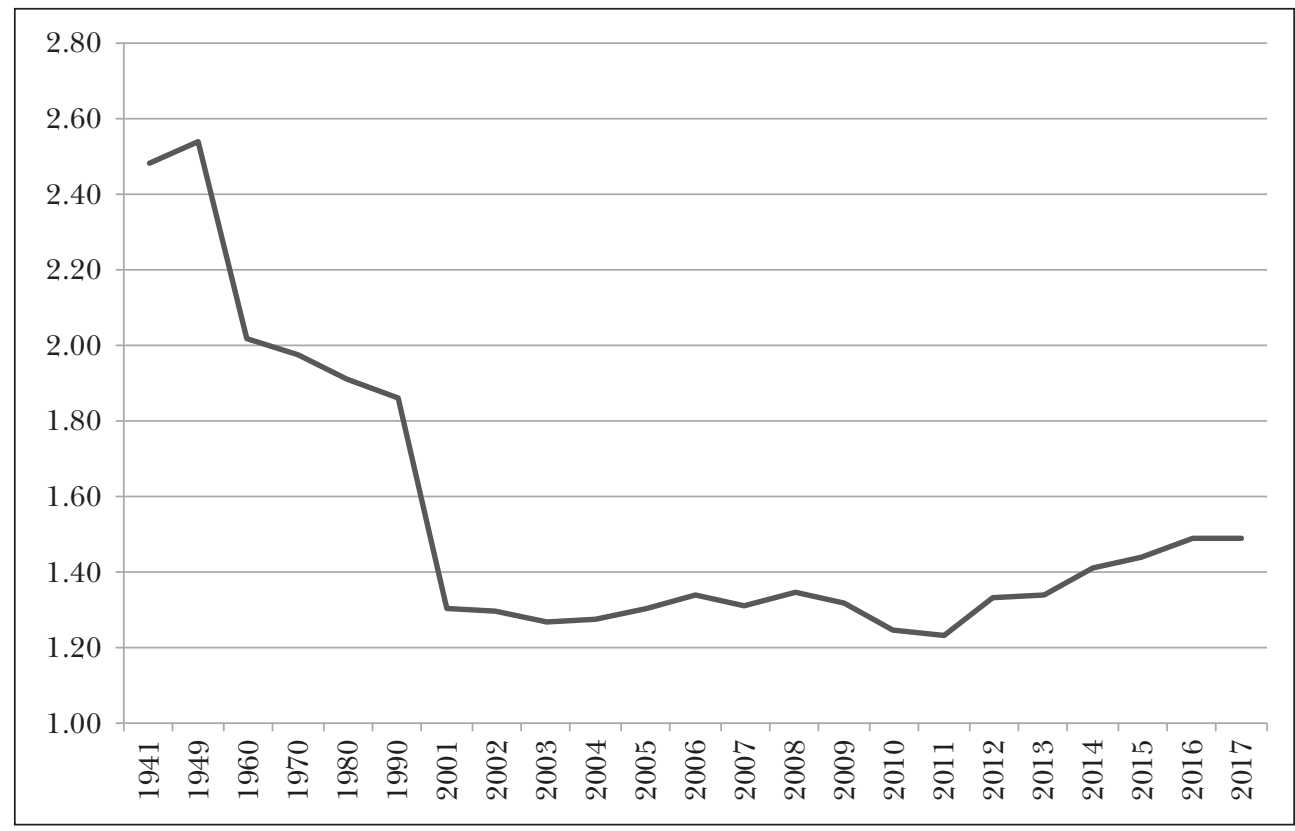

Source: Central Statistical Office of Hungary

velopments in Hungarian GDP per capita as a percentage of the corresponding Austrian figures, while the right one measures developments in the fertility rate. Only the years between 1991 and 2017 are analysed because the World Bank has only published SNA-indicator statistics for the former socialist countries since 1990.

The chart illustrates that relative to Austria, Hungary now has a higher standard of living than at the beginning of the 1990's. Due to reasons mentioned above, closing the gap is perhaps not readily perceived, and in addition, similarly to the other European countries, there are significant regional differences in convergence. Also note that after 2011 increase in the fertility rate was associated with a catch-up in the standard of livin.

Chart 5 highlights the unclear correlation between the fertility rate and the standard of living. Based on a time-series analysis, the question arises how GDP per capita and fertility rates develop after 1990.

The regression monogenic takes the form of a polynomial chart, and the cloud of points moderately matches the hypothetical regression line. The conclusion drawn from this chart is none different from the previous ones: at the beginning of the period reviewed, the fertility rate decreases in the wake of GDP growth, and then, after a certain point, it increases. In an excessively theoretical field, it may be concluded that having reached a certain per capita GDP, the Hungarian economy has entered ther range of low positive correlation between rise in the standard of living in an economic sense and fertility rate. Departing from the meaning of the model, reference needs to be made to the fact that the transformations that followed the change of 


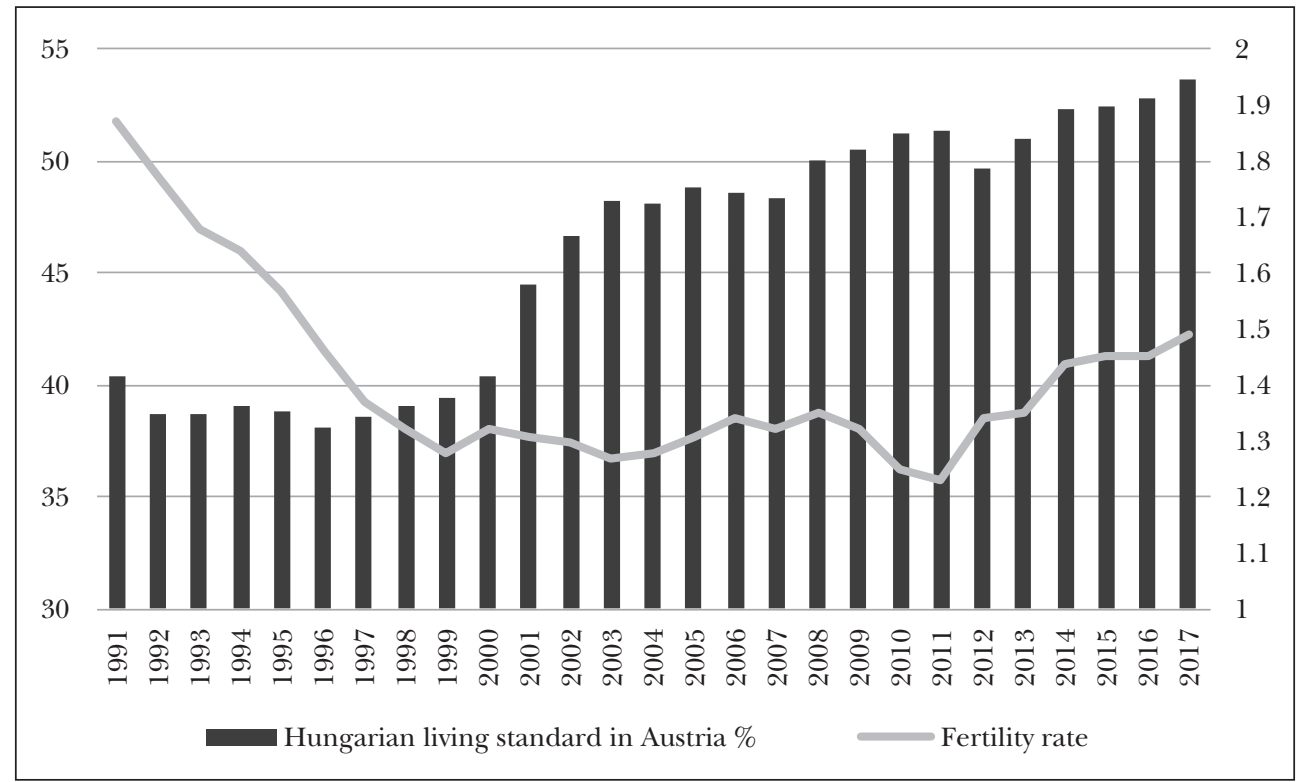

Source: Based on the data of Central Statistical Office of Hungary and World Bank

Chart 5: Regression monogenic between the fertility rate and GDP per capita after 1990

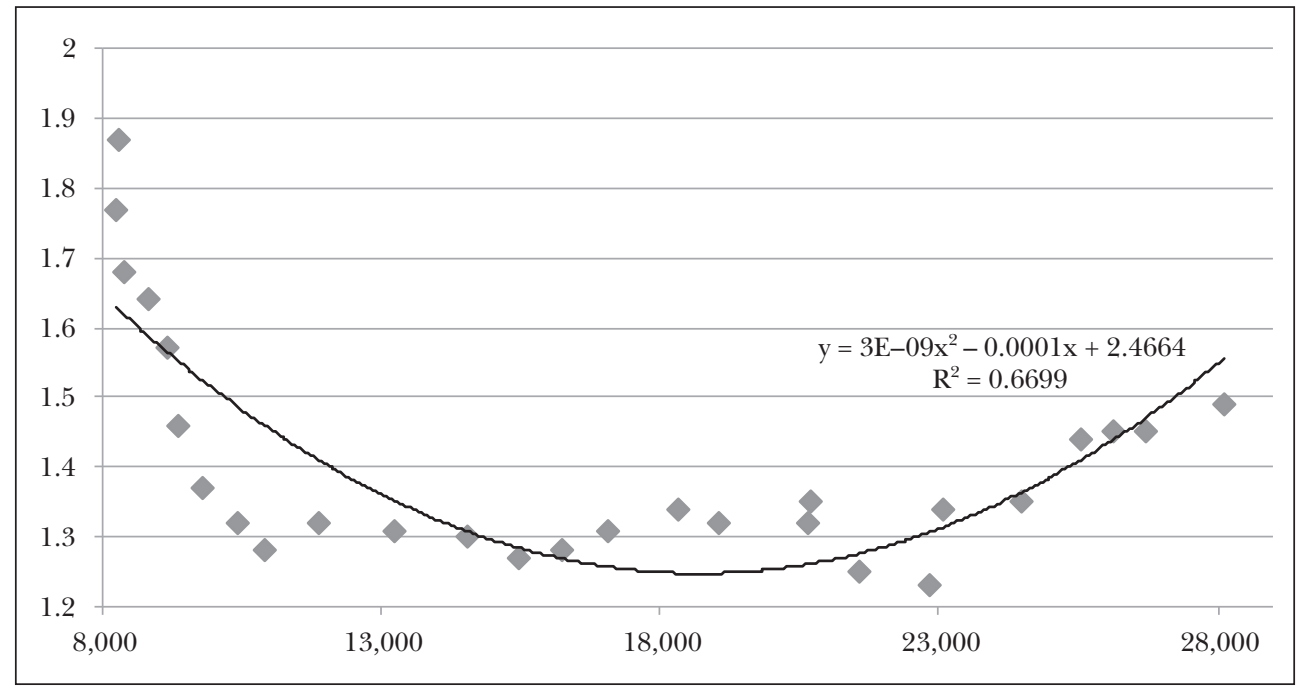

Source: Based on data from the Central Statistical Office of Hungary and the World Bank

regime and the shift in social values might also have had a serious impact on demography, and then the experiences gained about the new regime and the altered government policy could shift the demographic trend in a more favourable direction. 
These are evidenced by the findings of a survey conducted among Hungarian university students by Sági et al. (2017). More than a thousand interviewed students clearly expressed favourable opinions on the Hungarian family support system, including financial support and transfers. The overwhelming majority of the respondents considered the fiscal policy incentives beneficial for having children. Another research also pointed out that the family support and home creation aid applied in Hungary is sustainable over the longer term (Tatay et al., 2019).

Table 2: Differences between various NUTS 2 regions in Hungary

\begin{tabular}{l|c|c|c|c|c|c|c|c|c|c}
\hline \multirow{2}{*}{ Region } & \multicolumn{2}{|c|}{2001} & \multicolumn{2}{c|}{$\mathbf{2 0 0 5}$} & \multicolumn{2}{c|}{2010} & \multicolumn{2}{c|}{$\mathbf{2 0 1 5}$} & \multicolumn{2}{c}{2017} \\
\cline { 2 - 11 } average\% & $\begin{array}{c}\text { Live } \\
\text { residents }\end{array}$ & $\begin{array}{c}\text { GDP } \\
\text { average } \\
\%\end{array}$ & $\begin{array}{c}\text { Live } \\
\text { births/1000 } \\
\text { residents }\end{array}$ & $\begin{array}{c}\text { GDP } \\
\text { average } \\
\%\end{array}$ & $\begin{array}{c}\text { Live } \\
\text { births/1000 } \\
\text { residents }\end{array}$ & $\begin{array}{c}\text { GDP } \\
\text { average } \\
\%\end{array}$ & $\begin{array}{c}\text { Live } \\
\text { births/1000 } \\
\text { residents }\end{array}$ & $\begin{array}{c}\text { GDP } \\
\text { average, } \\
\%\end{array}$ & $\begin{array}{c}\text { Live } \\
\text { births/1000 } \\
\text { residents }\end{array}$ \\
\hline $\begin{array}{l}\text { Central } \\
\text { HU. }\end{array}$ & 157.7 & 9.1 & 162.4 & 9.9 & 165.8 & 9.8 & 153.5 & 9.4 & 152.9 & 9.2 \\
\hline $\begin{array}{l}\text { Central } \\
\text { Trans- } \\
\text { danubia }\end{array}$ & 92.5 & 9.1 & 94 & 9.3 & 86.6 & 8.7 & 93.1 & 9.1 & 92.3 & 9 \\
\hline $\begin{array}{l}\text { Western } \\
\text { Trans- } \\
\text { danubia }\end{array}$ & 102.3 & 8.7 & 98.9 & 9 & 99 & 8.2 & 107.9 & 8.3 & 105.6 & 8.5 \\
\hline $\begin{array}{l}\text { Southern } \\
\text { Trans- } \\
\text { danubia }\end{array}$ & 73.2 & 9.1 & 69 & 9.1 & 67.5 & 8.2 & 64.9 & 8.5 & 66.3 & 8.5 \\
\hline $\begin{array}{l}\text { Northern } \\
\text { HU }\end{array}$ & 65.7 & 10.1 & 66.2 & 9.8 & 60.1 & 9.2 & 66.3 & 9.9 & 67.4 & 10.4 \\
\hline $\begin{array}{l}\text { Northern } \\
\text { Great } \\
\text { Plain }\end{array}$ & 68 & 10.8 & 64.4 & 10.3 & 63.4 & 9.1 & 63.7 & 10.1 & 63.5 & 10.2 \\
\hline $\begin{array}{l}\text { Southern } \\
\text { Great } \\
\text { Plain }\end{array}$ & 73.8 & 9 & 68.9 & 9 & 64.8 & 8 & 71.7 & 8.6 & 71.2 & 8.9 \\
\hline
\end{tabular}

Source: Based on the data of Central Statistical Office of Hungary

Table 2 shows developments in live births per 1000 residents in the 7 NUTS- 2 regions in Hungary. As clearly visible, while live births give different rates in different years, the economic sequence of regions shows a stable picture. The Pearson correlation indicator of these 7 regions gives the following data for the years reviewed: -0.4587 ; $0.1439 ; 0.5434 ;-0.1372 ;-0.283$. In addition to the rates, the precursor also changes. In 2001, 2015 and in 2017 we can see a negative correlation between the standard of living and births (in 2001 it is medium), while in 2005 and 2010 this correlation is positive (in 2010 it is medium). Consequently, in certain years the number of births is higher with ssimilarly high welfare indicators, while in others the number of births is higher despite lower standard of living. Although more reliable results are obtained in deeper 
territorial levels, or even on a county level, at present the focus of the number of births is not necessarily at the place where economic indicators would justify.

In a global and a European perspective, Hungary belongs to the group of countries with a positive correlation between the standard of living in the economic sense and the fertility rate. For this reason, it is worth to take policy actions to support the financial aspects of childbearing. This is also confirmed by the recent improvement in the fertility rate in Hungary. Based on model calculations, the Hungarian family support model is sustainable also in terms of public finance. However, the globally negative correlation between the standard of living and the fertility rate, and the spatial processes within Hungary suggest that the factors underlying fertility also include factors beyond the economy (meta-economic factors). Certainly, a cultural and political stance against the concept of humans that can be associated with excessive individualisation may also be instrumental in achieving a more positive trend in this concept (Lentner et al., 2017).

\section{SUMMARY AND CONGLUSIONS}

The most important objective of this study is to clarify whether there is a valid correlation between development in the economic sense and the fertility rate. The conclusions drawn from the research findings show a controversial relationship. On the one hand, the fertility rate is high in countries where the standard of living is low, or at least below the average. This negative correlation between the two variables is only confirmed by a rapid decline in the fertility rate since the 1960's, parallel with a reapid rise in average GDP per capita. Thus in a global context, increase in the standard of living results in a decline in fertility. Naturally, it cannot be predicted to what extent the fertility rate will continue to decline, perhaps the trend will slow as it approaches the value 2, or at least this conclusion arises from the analysis of the current path.

However, in the Member States of the European Union the correlation between the standard of living and fertility rate is surprisingly different: at a point the correlation takes a positive direction, although it must be added that the detectable positive correlation is not high. In this group of developed countries, almost without an exception, there is a problem with biological regeneration, i.e. without a positive migration balance, their population declines. Under these conditions, in the context of economic development, the absence of corruption, employment and social and economic openness to novelties, the reviewed data shows a positive correlation with the fertility rate. Accordingly, it may seem justified to support the dynamics of the fertility rate in a country by the corresponding financial incentives. This does not mean that there are no other, more powerful means to achieve this goal but - contrary to the author's expectations - there is some room for manoeuvre for the financial support of the fertility rate: labour market predictability and a household income sufficient to cover the expenses seem to stimulate fertility. However, it should also be pointed out that an analysis over a longer timeframe may be justified, and that this model leaves the overall demographic picture of the 28 EU Member States unchanged. Low fertility is also a major problem in other developed areas from North America to Southeast 
Asia. The question may also arise whether people in developed societies overestimate the economic implications of having children or undertake unnecessarily excessive financial burdens to guarantee their upbringing and careers. This might be a rightful conjecture, and yet it seems that at the current standard of living having children does indeed have serious financial implications. Moreover, in addition to financial needs, requirements related to risk reduction, the stability of the institutional system and the maintenance of a welfare system also arise when it comes to supporting fertility in these countries, including of cours Hungary (although not necessarily by the classical means as the values shown by OECD countries reveal).

The complexity of the issue naturally requires a more complex approach. Sociological and psychological parameters suitable for capturing considerations beyond an individual's life-span, isolated interests and perception of usefulness should also be included in subsequent studies. As John D. Mueller suggests, transcendence and religious belief may be very important factors in supporting fertility (weekly church attendance shows the strongest correlation with fertility in the federal states of the US), and the existence and reinforcement of the positive and modern self-image and identity of a country - and as a higher quality, a nation, may possibly also serve this purpose.

\section{REFERENCES}

Barro, R. (2013): Health and Economic Growth. Annals of Economics and Finance, Vol. 14, No. 2.

Becker, G. S. (1960): An Economic Analysis of Fertility. In: Roberts, G. B (ed.): Demographic and Economic Change in Developed Countries. NBER, Boston, pp. 209-240.

Berde, É. and Kovács, E. (2016): A svéd és a magyar termékenységi arányszám összehasonlítása [A comparison of Swedish and Hungarian fertility rates]. Közgazdasági Szemle, Vol. 63, No. 12, pp. 1348-1374, https://doi.org/10.18414/ksz.2016.12.1348.

Berde, É. and Kuncz, I. (2017): Possible Paths for GDP Per Capita - Simulation with a Demographic Growth Model. Financial and Economic Review, Vol. 16, No. 4, pp. 36-57, http://doi.org/10.25201/FER.16.4.3657.

Berde, É. and Németh, P. (2016): A magyarországi termékenység paritásonkénti alakulása 1970 és 2011 között [Developments in fertility per parity in Hungary between 1970 and 2011]. Köz-gazdaság, Vol. 11, No. 2, pp. 129-148.

Dusek, T. and Kotosz, B. (2016): Területi statisztika [Territorial statistics]. Akadémiai Kiadó, Budapest, https://doi.org/10.1556/9789634540014.

Farkas, T. (2017): Lengyelország, Csehország és Szlovákia családtámogatási rendszereinek összehasonlítása [A comparison of family support regimes in Poland, Czechia and Slovakia]. Demográfia, Vol. 60, No. 4, pp. 333-376, https://doi.org/10.21543/dem.60.4.3.

Giday, A. and Szegô, Sz. (2018): Towards the "Child-to-Parent" Based Pension Allowance ("C2P"). Polgári Szemle/Civic Review, Vol. 14, Special Issue, pp. 302-319, https:/ /doi.org/10.24307/psz.2018.0420.

Hussain, S.; Malik, S. and Hayat, M. K. (2009): Demographic Transition and Economic Growth in Pakistan. European Journal of Scientific Research, Vol. 31, No. 3, pp. 491-499.

Jones, L. E. and Schoonbroodt, A. (2010): Fertility Theories: Can They Explain the Negative FertilityIncome Relationship? In: Shoven, J. B. (ed.): Demography and the Economy. NBER, Boston, pp. 43-100, https://doi.org/10.7208/chicago/9780226754758.003.0003.

Kucséber, L. Z. (2011): A munkanélküliség gazdasági és társadalmi következményei [The economic and social consequences of unemployment]. In: Róbert P. (ed.): Magyarország társadalmi-gazdasági helyzete a 21. század elsố évtizedeiben [Hungary's social and economic situation in the first decade of the 21st century]. Széchenyi István Egyetem, Gyôr, pp. 195-203. 
Lentner, Cs.; Novoszáth, P. and Sági, J. (2017): A magyar családpolitika és a születésszám alakulásának egyes kiemelt területei demográfiai, szociológiai és állampénzügyi vetületben, nemzetközi kitekintéssel [Certain highlighted areas in developments in Hungarian family policy and in the birthrate in the perspectives of demography, sociology and public finances]. Pro Publico Bono - Magyar Közigazgatás, Vol. 5, No. 4, pp. 106-133.

Malthus, T. (1998) [1798]: An Essay on the Principle of Population. Electronic Scholarly Publishing Project, London, www.esp.org/books/malthus/population/malthus.pdf.

Mason, A.; Lee, R. and Lee, S. (2010): The Demographic Transition and Economic Growth in the Pacific Rim. In: Ito, T. and Rose, A. (eds.): The Economic Consequences of Demographic Change in East Asia. University of Chicago Press, Chicago, https://doi.org/10.7208/chicago/9780226386881.003.0002.

Molnár, T. (2015): Empirikus területi kutatások és módszerek [Empirical regional surveys and methods]. Akadémiai Kiadó, Budapest.

Mueller, J. D. (2010): Redeeming Economics. Rediscovering the Missing Element. ISI Books, Wilmington.

Prskawetz, A. and Lindh, T. (eds.) (2007): The Relationship Between Demographic Change and Economic Growth in the EU. Institut für Demographie Österreichische Akademie der Wissenschaften, Wien.

Sági, J.; Tatay, T.; Lentner, Cs. and Neumanné Virág, I. (2017): Certain Effects of Family and Home Setup Tax Benefits and Subsidies. Public Finance Quarterly, Vol. 62, No. 2, pp. 171-187.

Sági, J. and Lentner, Cs. (2018): Certain Aspects of Family Policy Incentives for Childbearing - a Hungarian Study with an International Outlook. Sustainability, Vol. 10, No. 11, pp. 1-16, https://doi.org/10.3390/ su10113976.

Sági, J.; Lentner, Cs. and Tatay, T. (2018): Family Allowance Issues. Hungary in Comparison to Other Countries. Polgári Szemle/Civic Review, Vol. 14, Special Issues, pp. 290-301, https://doi.org/10.24307/ psz.2018.0419.

Schultz, Th. W. (1974): Fertility and Economic Values. In: Schultz, Th. W. (ed.): Economics of the Family: Marriage, Children and Human Capital. NBER, Boston, pp. 3-22.

Sobotka, T.; Skirbekk, V. and Philipov, D. (2011): Economic Recession and Fertility in the Developed World. Population and Development Review, Vol. 37, No. 2, pp. 267-306, https://doi.org/10.1111/j.17284457.2011.00411.x.

Széll, K. (2010): Idôsödô társadalom és az oktatási rendszer [Ageing society and the educational system]. Statisztikai Szemle, Vol. 88, No. 3, pp. 273-304.

Tatay, T.; Sági, J. and Lentner, Cs. (2019): A családi otthonteremtési kedvezmény költségvetési terheinek elôreszámítása, 2020-2040 [The preliminary calculation of the central budget costs of benefits for starting a family and for home creation]. Statisztikai Szemle, Vol. 97, No. 2, pp. 192-212, https://doi. org/10.20311/stat2019.2.hu192.

Tomka, B. (2016): Gazdasági növekedés, fogyasztás és életminôség. Magyarország nemzetközi összehasonlításban az elsố világháborútól napjainkig [Economic growth, consumption and the quality of life. Hungary in an international comparison from World War I to date]. Akadémiai Kiadó, Budapest.

Varga, B. (2005): A magyarországi termékenységi mozgalom területi különbségei [Territorial differences in the fertility movement in Hungary]. Gazdaságtudományi Közlemények, Vol. 4, No. 1, pp. 52-63.

Yang, H. (2000): Education, Married Women's Participation Rate, Fertility and Economic Growth. Journal of Economic Development, Vol. 25, No. 2, pp. 101-118.

Yang, Z. (2016): An Agent-Based Dynamic Model of Politics, Fertility and Economic Development. Journal of Systemics, Vol. 14, No. 1, pp. 68-72.

\section{OFFICIAL DATA SOURGES:}

Central Statistical Office of Hungary: http://www.ksh.hu/

World Bank: https://data.worldbank.org/ 